\title{
CITRICULTURE ECONOMIC AND FINANCIAL EVALUATION UNDER CONDITIONS OF UNCERTAINTY ${ }^{1}$
}

\author{
DANILO SIMÕES ${ }^{2}$, ANTÔNIO CARLOS CABRAL ${ }^{3}$, PAULO ANDRÉ DE OLIVEIRA ${ }^{4}$
}

ABSTRACT - The citriculture consists in several environmental risks, as weather changes and pests, and also consists in considerable financial risk, mainly due to the period of return on the initial investment. This study was motivated by the need to assess the risks of a business activity such as citriculture. Our objective was to build a stochastic simulation model to achieve the economic and financial analysis of an orange producer in the Midwest region of the state of Sao Paulo, under conditions of uncertainty. The parameters used were the Net Present Value (NPV), the Modified Internal Rate of Return (MIRR), and the Discounted Payback. To evaluate the risk conditions we built a probabilistic model of pseudorandom numbers generated with Monte Carlo method. The results showed that the activity analyzed provides a risk of $42.8 \%$ to reach a NPV negative; however, the yield assessed by MIRR was $7.7 \%$, higher than the yield from the reapplication of the positive cash flows. The financial investment pays itself after the fourteenth year of activity.

Index terms: risk analysis, Citrus sinensis Osbeck, agricultural economics, Monte Carlo.

\section{AVALIAÇÃO ECONÔMICO-FINANCEIRA DA CITRICULTURA NO CENTRO-OESTE DO ESTADO DE SÃO PAULO SOB CONDIÇÕES DE INCERTEZA}

\begin{abstract}
RESUMO - A atividade da citricultura é caracterizada por diversos riscos da atividade agrícola, como clima e pragas, e também por considerável risco financeiro, sobretudo devido ao prazo de retorno do investimento inicial. A necessidade de avaliar os riscos de uma atividade empresarial, como a cultura de citros, motivou este trabalho. O objetivo deste trabalho foi construir um modelo de simulação estocástico para realizar a avaliação econômico-financeira de um produtor de laranja da região centro-oeste do Estado de São Paulo, sob condições de incerteza. Os parâmetros utilizados foram o Valor Presente Líquido (VPL), a Taxa interna de Retorno Modificada (TIRM) e o Payback descontado. Para se avaliar as condições de risco, construiu-se um modelo probabilístico de números pseudoaleatórios, gerados com o método de Monte Carlo. Concluiuse que a atividade analisada proporciona o risco de $42,8 \%$ para que o VPL se torne negativo; contudo, a rentabilidade avaliada pela TIRM foi de 7,7\%, acima da proporcionada pela reaplicação dos fluxos positivos de caixa. $\mathrm{O}$ investimento financeiro paga-se após o décimo quarto ano de atividade.
\end{abstract}

Termos para indexação: Análise de risco, Citrus sinensis Osbeck, engenharia econômica, Monte Carlo.

${ }^{1}$ (Trabalho 257-14). Recebido em: 23-09-2014. Aceito para publicação: 23-01-2015.

${ }^{2}$ Administrador de empresas, Professor Doutor, Centro Estadual de Educação Tecnológica Paula Souza. E-mail: simoesdanilo@yahoo. com.br

${ }^{3}$ Discente de graduação em Produção Industrial, Centro Estadual de Educação Tecnológica Paula Souza. E-mail: carlos.cabral@ r7.com

${ }^{4}$ Economista, Professor Doutor, Centro Estadual de Educação Tecnológica Paula Souza. E-mail: poliveira@fatecbt.edu.br 


\section{INTRODUCTION}

Brazil is the biggest citrus producer and the leading exporter of orange juice (TOFFANO et al., 2012), being the sweet orange (Citrus sinensis Osbeck), the most produced species (AZEVEDO et al., 2010).

Nascimento et al. (2010) stated that it has been a while since the citriculture became an important agribusiness in Brazil, especially in the State of Sao Paulo. The city of Botucatu, located at the Midwest of the state, has a great interest in this sector since it is an area free of the major citrus diseases.

Regardless the region, citriculture is not different from other agriculture activities, because it also consists in an ambient with risks, whether risks of market, biological, phytosanitary, or changes in weather that could compromise the crop economic viability. Despite the complexity of determining these events occurrence, it is possible to determine and mitigate the uncertainties that can enhance these risks levels, mainly the economic-financial risk, for instance, the application of mathematical models.

According to Souza and Clemente (2008), the uncertainty affects the investment cash flow, thus, the project return. This way, the project value and the investment decision would be affected by the uncertainty of the variables that impact the investment.

Thereat, the critical variables of a project should be determined, their probability distributions and correlations estimated, and a distribution of values for the present value of the project could be obtained (MINARDI; SAITO, 2007). When estimating the probability of an event occurrence, one can simulate a number of independent samples of the event and compute the proportion of the times that it occurs (ANGELOTTI et al., 2008).

Noronha et al. (2014) reported that numerous model scenarios are calculated in the simulation, by a draft of the values from the random variables probability distribution. Woiler and Mathias (1988) argue that the use of simulation techniques improve the analysis of decision-making risk.

Through simulations, one may obtain the risk indicators: sensibility, standard deviation, coefficient of variation, maximum and minimum values, and the cumulative probability distribution of the output variable, which measures the return under conditions of risk (ARÊDES, 2006).

The stochastic simulation model construction consists, initially, in determining the variables that may exert greater influence on the analyzed system, so-called endogenous variables, which will expose the aspects of interest, and exogenous variables that have essential and determining implications in decision making.

To perform a stochastic simulation, we can use the Monte Carlo method, which, according to Martins et al. (2011), consists in the generation of pseudorandom numbers from a real sample. To Oliveira and Pamplona (2012) in the Monte Carlo method, the main project uncertainty sources that can serve as input variables for the simulation can be: revenue, discount rates, costs, and expenses, among others.

From the above, we aimed to build a model of stochastic simulation to achieve the economic and financial evaluation of an orange producer in the Midwest region of the state of Sao Paulo, under conditions of uncertainty.

\section{MATERIAL AND METHODS}

The analysis included agricultural activities related to the formation of the orchard until the end of the crop life cycle, estimated in 17 years. The following data were weighted to the production process: operational efficiency (man hours and machine hours per hectare); quantity of orange seedlings (planting and replanting); machinery maintenance and improvements; fertilizers; agricultural pesticides; soil analysis; administration fee; diesel oil; thinning; ant control; contracted and third party labor; inspections of greening, pests and diseases; disposal of contaminated plants; macro and micro nutrients spraying, to control fruit fly and citrus leprosis.

To estimate the economic feasibility of investment project, we used the matrix of technical coefficients of a citrus producer who produces five varieties of orange (Citrus sinensis Osbeck), Valencia, Pear, Ruby, and Westin Hamlin, in a total area of 2,932 hectares. The orange seedlings were grafted on Rangpur lime (Citrus limonia), and planted in spacing of $7 \times 4 \mathrm{~m}$ (357 trees per hectare).

The study area is located in the State of Sao Paulo, Midwestern region, belonging to the Office of Rural Development (EDR) of Botucatu, SP. The soil type found in the area, according to the soil map described by Oliveira et al. (1999), are Dystrophic Red Oxisol and Entisols. Classified according to Wilhelm Köeppen, this area belongs to $\mathrm{Cw}$ climate, corresponding to Mesothermal humid climate type, with low water deficiency (B2Rb'4a'), according to Thorntwaite.

Production costs were estimated according 
to the methodology used by the Brazilian Institute of Agricultural Economics (IEA), proposed by Matsunaga et al. (1976), classified into Effective operational cost (COE), Total operating cost (TOC), and Total cost of production (CTP). Agricultural machinery operating costs were estimated using the methodology proposed by the American Society of Agricultural and Biological Engineers (ASABE, 2006a; ASABE, 2006b).

The costs were expressed in American dollars, as it is the international reference currency (SIMÕES et al., 2012) and utilized as parameter in the financial market (COELHO JUNIOR et al., 2008). The dollar rate price was obtained from the Banco Central do Brasil (PTAX 800) official foreign exchange price measured in fractions and units of the Brazilian national currency, which was R\$ 2.3916 on 02/10/2014 (BANCO CENTRAL DO BRASIL, 2014a).

The evaluation of the project was done based on the Discounted Cash Flow (DCF), which, according to Minardi (2000), is accepted with a planning horizon of 17 years. Although, one of the DCF limitations is that it does not take in consideration some important fractions of the project (TRIGEORGIS, 1996). Therefore, we considered the Legal Entity Income Tax, with aliquot of $15.0 \%$ on the profit and the additional of the $10.0 \%$ on the surplus of the profit, and $9.0 \%$ the Social Contribution on the Net Profit, since the form of taxation is Actual Profit.

The incorporation of risk to the financial investment project was performed with 100,000 Monte Carlo stochastic method simulations with stratified probability distribution. The pseudorandom number generator Mersenne Twister was used (MATSUMOTO; NISHIMURA, 1998).

The simulations, data descriptive statistics, and Spearman's rank-order correlation coefficient $r_{s}$ (SPEARMAN, 1904), applied to check the input variables inter-relationship, were performed using@Risk for Excel software (PALISADE CORPORATION, 2014).

The Autoregressive Integrated Moving Average (ARIMA) model proposed by Box and Jenkins (1970) by the selection criterion Bayes Information Criteria (BIC) developed by Schwarz (1978), was adopted to the following projections:

- considering a pessimistic scenario, where the citrus producers need to apply for loans from the capital market. Thereby, we used data from the economic and financial time series related to the Special Settlement and Custody System (SELIC) provided by Banco Central do Brasil (2014b), observed between January, 2007 and June, 2014;

- agricultural land value projected from the time series of the study area EDR, provided by the Instituto de Economia Agrícola (2014), observed between February, 1995 and June, 2013, to estimate the opportunity cost of land;

- inflation rate projected for the purpose of updating the project administration and orange harvesting and transportation costs, paid during the series of cash flows. We used data from the economic and financial time series for the National Consumer Price Index (IPCA) provided by the Banco Central do Brasil (2014b), observed between January, 2004 and June, 2014;

- orange industry pricing, designed from the price time series data from the state orange industry (out of contract) provided by the Centro de Estudos Avançados em Economia Aplicada - CEPEA (2014) between October, 1994 and March , 2014.

These orange marketing prices are available in the units of Brazilian national currency. So, for conversion into commercial American dollar (PTAX $800)$, we used the monthly average exchange prices provided by the Fundação Getúlio Vargas (2014).

For the stochastic simulation model, used to identify the uncertainties associated to the citriculture, there were considered 15 input variables as follows: orchard implementation cost (USD ha-1); cost of orchard cultivation for the first year (USD ha ${ }^{-1}$ ); cost of orchard cultivation for the second to the third year (USD ha-1); cost of orchard cultivation for the forth to the seventeenth year (USD ha-1); orange production (box ha ${ }^{-1}$ ) in the orchard in the third year; orange production (box ha-1) in the orchard in the fourth year; orange production (box ha-1) in the orchard in the fifth year; orange production (cash ha-1) in the orchard from the sixth to the seventeenth year; costs of orange harvesting and transportation (USD ha-1); cost of administration (USD ha-1); orange industry pricing (USD box ${ }^{-1}$ ); agricultural land value (USD $\left.\mathrm{ha}^{-1}\right)$; savings interest income (\%); IPCA (\%); and SELIC rate $(\%)$.

Due to no knowledge of each variable distribution that highly influences the financial outcome of the project, the triangular distribution was applied. Lyra et al. (2010) explain that given the difficulty of identifying the probability distributions of each relevant variable, this is the most usual procedure. To set the minimum input, mode, and maximum values, a variant of $-15.0 \%$ to $+15.0 \%$ of the deterministic values was delimited, except for: industry orange pricing; total savings interest income; and Selic rate, which were delimited by the moving averages. 
The economic feasibility indicators, considered as the stochastic simulation model output variables, were: Net Present Value (NPV) as proposed by Pimentel et al. (2007); Modified Internal Rate of Return according to Barbieri et al. (2007); Discounted Payback according to Frank et al. (2011), commonly used for long-term financial investment analysis.

\section{RESULTS AND DISCUSSION}

The economic importance of the citriculture activity has stimulated numerous studies in order to analyze various aspects related to its production system (FIGUEIREDO et al., 2009). However, as any other agricultural activity, it is subject to risks (PAES et al., 2005).

According to Dixit and Pindyck (1994), the investment under uncertainty involves characteristics as irreversibility, uncertainty, and timing. Every investment is at least partially irreversible, because its initial cost can be considered a sunk cost. This means that, if the alternative more viable is to suspend the decision to finance the investment during the project development, part of the cost that had already been incurred will not be recovered.

Risks can be identified from the costs of implementation and management practices of this crop. For the production system here evaluated, the estimated mode value of the orange orchard deployment was USD 2,117.43 per hectare, value in closely agreement to the one obtained by Paes and Esperancini (2006), who considered similar conditions as found in this study. Over the orchard useful life, the producer will spend a mode value of USD 1,183.90 with the cultural practices, annually. The most likely total cost of production is USD $1,705.35$ per hectare, resulting in a mode value of USD 1.60 per box of oranges produced.

The productivity in citrus can be expressed, among other possibilities, in boxes per hectare (CASER; AMARO, 2004). Therefore, we adopted the number of boxes sold, standardized by the citrus sector with $40.8 \mathrm{~kg}$.

According to Adami (2010), productivity affects the revenue of the citriculture. Although the data used in the study came from real situations, the most likely yield obtained by the stochastic simulation model for the third year of production (1st harvest) was 500 boxes; 1,000 boxes in the fourth year; 1,250 boxes in the fifth year; and 1,500 boxes in the sixth to the seventeenth year of production.

When the costs of harvesting and transportation are not assumed by the juice industry, these are assumed by the producer (PAULILLO et al., 2006). Thereby, as the producer in this study does not have contracts with the processing industry, the cost of harvesting and transportation resulted in a mode value of USD 1.88 per box.

According to Paes et al. (2004), prices received by the producers from the juice industry for the orange box are directly related to its price in the international market. The supply, demand, and carryover stocks of frozen concentrated orange juice in the world market are reflected in the New York Stock Exchange, which indicate prices determined by the juice industry to be paid to the orange producer. Figueiredo et al. (2013) affirmed that to run an economic analyzes related to the orange juice industry, it is necessary to obtain price series that the producer receives for orange sold.

Thus, based on the ARIMA model by the BIC criteria, it was possible to model the time series of the orange price placed in the industry, assuming USD 4.23 per orange box sold. Santos et al. (2013) reported that the Brazilian orange juice industry went through a period of crisis in the second half of 2007, which was associated to the fall of commodity prices and to the decline in the global demand for the product. This fact can justify the sale price assumed by the model used in the prediction, which was approximately USD 0.20 lower than the last price paid to the producer, according to information available on the CEPEA of March, 2014.

According to the United States Department of Agriculture - USDA (2007), agricultural risks are generally organized into five categories: price risk (products and agricultural supplies); production risk; income risk; financial risk; and institutional risk (related to changes in laws or regulations).

This is corroborated with the data shown in Figure 1. Among the weighted inputs, we can observe that the largest economic and financial risk of the citrus production is associated to the cultivation cost of the fourth to the seventeenth year, because it presented a negative Spearman correlation to the Net Present Value (-0.37). The follow great economic and financial risk is first, the orange harvesting and transportation cost and then, the opportunity cost of land.

The industry orange pricing (USD box ${ }^{-1}$ ) and the quantity produced (box ha $\mathrm{a}^{-1}$ ) from the sixth to the seventeenth year are directly proportional to the VPL. The price of oranges has strong correlation $(0.85)$ with the NPV, indicating the influence and the risk that the product prices impact on the citriculture viability. The other inputs considered in the stochastic simulation model, did not demonstrated an impact on 
NPV due to their small Spearman correlation coefficient (-0.02). We adopted the Spearman correlation coefficient rank-order correlation coefficient $r_{s}$ as it is the algorithm used in the (a) Risk software. According to Gregório (2008), the Spearman correlation coefficient is commonly chosen because it does not require the variables normality assumption.

The basic principle of the Monte Carlo method is that the relative frequency of determined phenomenon tends to approximate the probability of occurrence of the same phenomenon, when the experiment is repeated several times; assuming random values to the phenomenon to be within the minimum and maximum limits (HERTZ, 1979).

Given this context, Figure 2 shows the cumulative frequency of simulated NPV of citrus production in the Midwest region of the State of Sao Paulo. There is a probability of $44.5 \%$ to this economic viability indicator to be negative, and the most likely value to be obtained is USD 2,198.40.

Assaf Neto and Lima (2009) claim that the risk measurement through the economic scenarios incorporates the probability distribution into the sensitivity study of a project, revealing to be useful to the financial manager. Machado Neto et al. (2013) add that the sensitivity analysis consists in measuring at each magnitude a predetermined change in one or more factors change the final result.

Therefore, the sensitivity analysis shows that, among the input variables analyzed by the triangular distribution, the price of industry orange has the greatest effect on the NPV, since the increase in the orange price by the industry at $5.0 \%$ on the price assumed by the ARIMA model could reduce the risk of the investment project in $19.3 \%$, which corroborates the sensitivity of this variable to the citriculture financial investment.

At a given time when the Brazilian agriculture performance is presented as a result of the innovation process, new approaches are demanded (VIEIRA FILHO; SILVEIRA, 2012). However, this process contributes to further aggravate the chronic lack of economic and statistical data in the citriculture chain (GHILARDI, 2006). Thus, projects of financial investment in citrus managed with statistical data can enable improvements in the result quality and minimize risks.

The descriptive statistics (Table 1) allows us to consider that the economic feasibility indicators skewness and kurtosis have approximately normal distribution, respectively close to 0 and 3 , corroborated by the proximity of the median to the mean and mode values obtained. Jobim et al. (2009) describes that the lower the probability distribution dispersion, the lower the risk. The variance and standard deviation of the distribution of an investment value measures the distribution dispersion, whereas the mean or expected value quantifies the associated risk.

Therefore, as observing the NPV, which according to Ross et al. (2002) is the long-term investment profitability most important measurement, it has the high financial risk that the citriculture has, due to the increase of the standard of deviation and variance values.

By analyzing the Modified Internal Rate of Return - MIRR, Solomon (1956) proposed an introduction to different rates, as the financial project net cash flows were positive or negative. Gonçalves et al. (2009) stated that the MIRR is calculated bringing all investment flows to the initial moment by the investment rate and taking the positive flows to the last moment by the reinvestment rate, and calculating the rate that makes the two flows equivalent, i.e., the return internal rate.

This way, the market interest rate, assumed by the time series based on the Selic rate was $10.9 \%$ per year, which can be considered quite conservative for rural credit. As the minimum rate of attractiveness and reinvestment of capital was assumed $6.2 \%$ per year, projected from the Banco Central do Brasil savings interest income history.

Although the most likely MIRR $(7.7 \%)$ is economically viable by allowing a greater return than the capital application in fixed income investments, by admitting the replicability of the intermediate cash flows and the need to raise funds in the financial market with the rates used to estimate the MIRR, there is a probability of $42.8 \%$ to the financial project result in a percentage equal to or below the attractiveness rate.

According to Debastiani et al. (2014), the Discounted Payback estimates the period of recovery from the investment by adjusting cash flows with an interest rate. Thereby, there is a probability of $95.0 \%$ that the citrus farmers recover the investment only after the fourteenth year of the project concession investment. This fact confirms the high risk that the citrus industry currently provides; due to the likelihood of a farmer to not recover the financial investment over the orchard life cycle. 


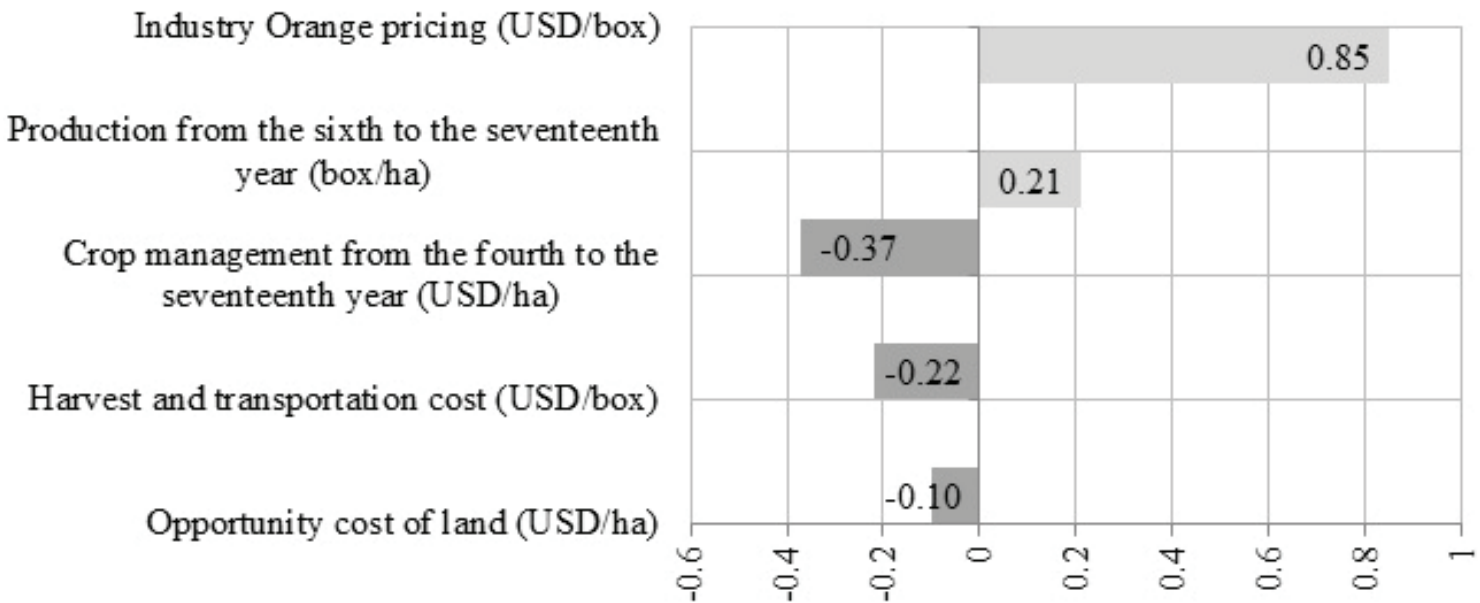

Correlation Coefficient

FIGURE 1 - Spearman correlation coefficient of the stochastic model of input variables, in relation to the NPV.

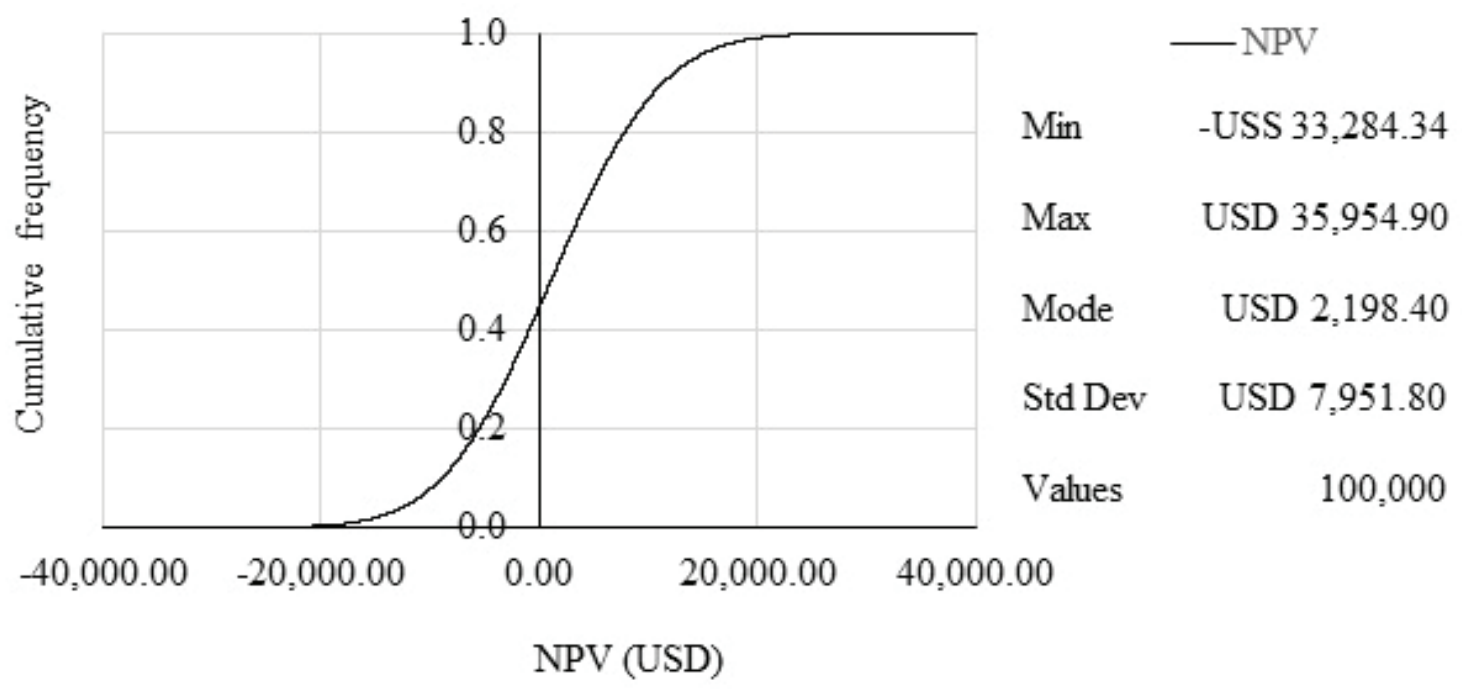

FIGURE 2 - Cumulative frequency of the NPV simulated for the citriculture in the Midwest region of the Sao Paulo state. 
TABLE 1 - Descriptive statistics of the orange production in the Midwest region of the State of Sao Paulo of the economic and financial feasibility indicators.

\begin{tabular}{|c|c|c|c|}
\hline Statistics & $\begin{array}{l}\text { NPV } \\
\text { (USD) }\end{array}$ & $\begin{array}{c}\text { MIRR } \\
(\%)\end{array}$ & Discounted Payback (years) \\
\hline Minimum & $-33,284.34$ & -100.00 & 0.0 \\
\hline Maximum & $35,954.90$ & 22.00 & 16.2 \\
\hline Average & $1,192.31$ & -4.72 & 5.2 \\
\hline Mode & $2,198.40$ & 7.71 & 0.0 \\
\hline Standard Deviation & $7,951.80$ & 5.77 & 5.2 \\
\hline Variance & $63,231,150.00$ & 0.1149263 & 11.987608 \\
\hline Skewness & 0.0653369 & 0.0615547 & 0.734466 \\
\hline Kurtosis & 3.050862 & 3.018869 & 3.188334 \\
\hline Errors & 0 & 0 & 0 \\
\hline \multicolumn{4}{|l|}{ Percentiles } \\
\hline $5 \%$ & $-11,719.84$ & -3.85 & 0.0 \\
\hline $15 \%$ & $-7,003.74$ & -710 & 0.0 \\
\hline $25 \%$ & $-4,195.42$ & 1.29 & 0.0 \\
\hline $35 \%$ & $-1,927.02$ & 4.52 & 0.0 \\
\hline $45 \%$ & 95.75 & 6.62 & 0.0 \\
\hline $55 \%$ & $2,103.51$ & 8.30 & 7.0 \\
\hline $65 \%$ & $4,179.63$ & 9.76 & 8.1 \\
\hline $75 \%$ & $6,481.68$ & 11.15 & 9.2 \\
\hline $85 \%$ & $9,423.74$ & 12.70 & 11.1 \\
\hline $95 \%$ & $14,396.43$ & 14.91 & 14.1 \\
\hline
\end{tabular}

\section{CONCLUSIONS}

The citriculture has a high risk to farmers that have no contract with the processing industry, and the probability of the NPV being negative is $44.5 \%$ in this study.

An increase of $5.0 \%$ in the price paid by the industries in the State of Sao Paulo may reduce in $19.3 \%$ the risk for producers who do not have contract with the processing industries.

The MIRR of $7.7 \%$ demonstrates that the activity has a higher profitability rate than the reinvestment rate of annually positive cash flows of $6.2 \%$.

The costs of management practices between the orchard on the fourth and seventeenth years are the variables that can derail the financial investment in citrus.

The orange harvesting and transportation cost $17.5 \%$ higher than the production cost of each orange box.

The citrus producers may, possibly, recover the capital invested after fourteen years of activities.

\section{REFERENCES}

ADAMI, A. C. O. Risco e retorno de investimento em citros no Brasil. 2010. 150 f. Tese (Doutorado em Economia Aplicada) - Escola Superior de Agricultura "Luiz de Queiroz", Universidade de São Paulo, Piracicaba, 2010.

ANGELOTTI, W. F. D.; FONSECA, A. L.; TORRES, G. B.; CUSTODIO, R. Uma abordagem simplificada do método Monte Carlo Quântico: da solução de integrais ao problema da distribuição eletrônica. Revista Química Nova, São Paulo, v. 31, n. 2, p. 433-444, 2008. Disponível em: $<$ submission. quimicanova.sbq.org.br/qn/qnol/2008/vol31n2/43ED07200.pdf> . Acesso em: 09 jul. 2014.

ARÊDES, A. F. Avaliação econômica de irrigação do cafeeiro em uma região tradicionalmente produtora. 2006. 108 f. Dissertação (Mestrado em Economia Aplicada) - Universidade Federal de Viçosa, Viçosa, 2006. 
ASABE - American Society of Agricultural and Biological Engineers. Agricultural machinery management. Michigan: American Society of Agricultural and Biological Engineers, 2006a. (EP496.3).

ASABE - American Society of Agricultural and Biological Engineers. Agricultural machinery management. Michigan: American Society of Agricultural and Biological Engineers, 2006b (D497.5).

ASSAF NETO, A.; LIMA, F. G. Curso de administração financeira. São Paulo: Atlas, 2009. 820 p.

AZEVEDO, F. A.; POLYDORO, D. A.; BATIANEL, M. KUPPER, K. C.; STUART, R. M.; COSTA, F. P.; PIO, R. M. Resposta de diferentes genótipos de tangerinas e seus híbridos à inoculação in vitro e in vivo de Alternaria alternata. Revista Brasileira de Fruticultura, Jaboticabal, v. 32, n. 3, p. 944-951, 2010. Disponível em: $<$ http://dx.doi.org/10.1590/ S0100-29452010005000085>. Acesso em: 9 jul. 2014.

BANCO CENTRAL DO BRASIL. Conversão de moedas. Disponível em: $<$ http://www4.bcb.gov. $\mathrm{br} / \mathrm{pec} /$ conversao/conversao.asp $>$. Acesso em: 17 mar. $2014 \mathrm{a}$

BANCO CENTRAL DO BRASIL. Estatísticas econômico-financeiras. Disponível em: $<\underline{\text { https:// }}$ www3.bcb.gov.br/sgspub/pefi300/telaCtjSelecao. paint>. Acesso em: 4 jul.2014b.

BARBIERI, J. C.; ÁLVARE, A. C. T.; MACHLINE, C. Taxa Interna de Retorno: controvérsias e interpretações. Gestão da Produção, Operações e Sistemas, São Paulo, v. 5, n. 2, p. 131-142, 2007. Disponível em: $<\underline{\text { http://revista.feb.unesp.br/index. }}$ php/gepros/article/view/184>. Acesso em: 07 jul. 2014.

BOX G, JENKINS G. Time series analysis: forecasting and control. 3rd ed. San Francisco: Holden-Day, 1970. 592p.
CASER, D. V.; AMARO, A. A. Evolução da produtividade na citricultura paulista. Informações Econômicas, São Paulo, v.34, n.10, 2004. Disponível em: $<$ http://www.iea.sp.gov.br/out/publicacoes/pdf/ tec1-1004.pdf $>$. Acesso em: 8 jul. 2014.

CEPEA - Centro de Estudos Avançados em Economia Aplicada. Séries mensais: laranja posta na indústria paulista (sem contrato). Disponível em: <http:// cepea.esalq.usp.br/citros $/$ ?page $=707>$. Acesso em: 5 jul. 2014.

COELHO JÚNIOR, L. M.; REZENDE, J. L. P.; OLIVEIRA, A. D.; BORGES, L. A. C.; SOUZA, A. N. Análise de investimento de um sistema agroflorestal sob situação de risco. Revista Cerne, Lavras, v. 14, n. 4, p. 368-378, 2008. Disponível em: $<$ www.dcf.ufla.br/cerne/artigos/artigo\%2011.pdf $>$. Acesso em: 7 jul. 2014.

DEBASTIANI, G.; NOGUEIRA, C. E. C.; LAWDER, J. H.; VIDOTTO, M.; AZEVEDO, R. L. Auditoria energética em uma agroindústria de laticínios. Revista Engenharia Agrícola, Jaboticabal, v. 34, n. 2, 2014. Disponível em: <http://dx.doi.org/10.1590/

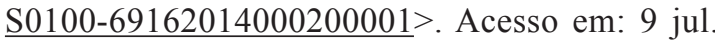
2014.

DIXIT, A.; PINDYCK, R. Investment under uncertainty. Princeton: Princeton University Press, 1994. $468 \mathrm{p}$.

FIGUEIREDO, M. G.; BARROS, A. L. M.; FRIZZONE, J. A. Consumo de fertilizantes e produtividade da laranja em São Paulo ao longo das décadas de 1970, 1980 e 1990. Revista de Economia e Sociologia Rural, Brasília, v. 47, n. 3, p. 637-650, 2009. Disponível em: <http://dx.doi. org/10.1590/S0103-20032009000300005>. Acesso em: 7 jul. 2014.

FIGUEIREDO, A. M.; SOUZA FILHO, H. M.; PAULILLO, L. F. Análise das margens e transmissão de preços no sistema agroindustrial do suco de laranja no Brasil. Revista de Economia e Sociologia Rural, Brasília, v. 51, n. 2, p. 331-350, 2013. Disponível em: <http://dx.doi.org/10.1590/S010320032013000200007>. Acesso em: 8 jul. 2014.

FUNDAÇÃO GETÚLIO VARGAS. Séries gratuitas: dólar comercial (ptax), cotações médias mensais. Disponível em: <http://www.antigofgvdados.fgv. br/chart/fgvdados $77201453 \quad 28 . \mathrm{htm}>$. Acesso em: 7 jul. 2014. 
FRANK, A. G.; SOUZA, D. V.; ECHEVESTE, M. E.; RIBEIRO, J. L. D. Sistemática para avaliação multicriterial de investimentos no desenvolvimento de produtos. Revista Production, São Paulo, v. 21, n. 4. p. 570-582, 2011. Disponível em: $<\underline{\text { http://dx.doi. }}$ org/10.1590/S0103-65132011005000060>. Acesso em: 07 jul. 2014.

GHILARDI, A. Análise comparativa de custos de produção de laranja para indústria, Estado de São Paulo, Safra 2005/2006. Citrus Research \& Technology, Cordeirópolis, v. 27, n. 2, p. 165-184, 2006. Disponível em: $<\underline{\text { http:// }}$ revistalaranja.centrodecitricultura.br/edicoes/down. php? idedicao $=15 \&$ arquivo $=01$ analise.pdf $>$. Acesso em: 9 jul. 2014.

GONÇALVES, A.; NEVES, C.; CALÔBA, G.; NAKAGAWA, M.; MOTTA, R. M.; COSTA, R. P. Engenharia econômica e finanças. Rio de Janeiro: Campus, 2009. 312p.

GREGÓRIO, A. C. Impacto das estratégias de saúde na organização do plano de contingência da pandemia de gripe do centro hospitalar do Barlavento Algarvio. 2008. 197 f. Dissertação (Mestrado em Gestão Empresarial) - Universidade do Algarve, Faro, 2008.

HERTZ, D. B. Risk analysis in capital investment. Harvard Business Review, Boston, v. 57, n. 5, p. 169-180, 1979. Disponível em: <http://hbr. org/1979/09/risk-analysis-in-capital-investment/ ar/1>. Acesso em: 8 jul. 2014.

INSTITUTO DE ECONOMIA AGRÍCOLA. Valor de terra nua. Disponível em: $<\underline{\text { http://ciagri.iea. }}$ sp.gov.br/nia1/precor.aspx?cod tipo $=1 \& \operatorname{cod}$ sis=8? $>$. Acesso em: 4 jul. 2014.

JOBIM, C. I.; MATTUELLA, J.; LOUZADA, J. A. Risco econômico do feijão irrigado no Rio Grande do Sul. Revista de Gestão de Água da América Latina, Porto Alegre, v. 6, n. 1, p. 67-77, 2009. Disponível em: <https://www.abrh.org.br/sgcv3/ UserFiles/Sumarios/81679a3e2735a55208cf37914 be5aabb d2347d85cd36d72d9e9d2a9298dc7be4. pdf>. Acesso em: 9 jul. 2014.
LYRA, G. B.; PONCIANO, N. J.; SOUZA, P. M. SOUSA, E. F.; LYRA, G. B. Viabilidade econômica e risco do cultivo de mamão em função da lâmina de irrigação e doses de sulfato de amônio. Acta Scientiarum. Agronomy, Maringá, v. 32, n. 3, p. 547-554, 2010. Disponível em: <http://dx.doi. org/10.4025/actasciagron.v32i3.2451>. Acesso em: 6 jul. 2014.

MACHADO NETO, A. S.; JASMIM, J. M.; PONCIANO, N. J. Indicadores econômicos da produção de flores tropicais no estado do Rio de Janeiro. Revista Ceres, Viçosa, v. 60, n. 2, p. 173-184, 2013. Disponível em: <http://dx.doi. org/10.1590/S0034-737X2013000200005>. Acesso em: 9 jul. 2014.

MARTINS, J. L. F.; FERREIRA, M. L. R.; SARAIVA, J. M. F. Estimativa da produtividade em soldagem pelo Método de Monte Carlo. Revista Soldagem \& Inspeção, São Paulo, v. 16, n. 3, p. 204-212, 2011. Disponível em: <http://dx.doi. org/10.1590/S0104-92242011000300002>. Acesso em: 9 jul. 2014.

MATSUNAGA, M.; BEMELMANS, P. F.; TOLEDO, P. E. N. de. Metodologia de custo de produção utilizado pelo IEA. Agricultura em São Paulo, São Paulo, v. 23, n. 1, p. 123-139, 1976.

MATSUMOTO, M.; NISHIMURA, T. Mersenne Twister: a 623-dimensionally equidistributed uniform pseudorandom number generator. ACM Transactions on Modeling and Computer Simulation,New York, vol. 8, n. 1, p. 3-30, 1998. Disponível em: $<\underline{\text { http://dl.acm.org/citation.cfm?id }}$ $=272995 \& \mathrm{dl}=\mathrm{ACM} \& \mathrm{coll}=\mathrm{DL} \& \mathrm{CFID}=507336727$ $\underline{\& C F T O K E N=74166780}>$. Acesso em: 7 jul. 2014.

MINARDI, A. M. A. F. Teoria de opções aplicada a projetos de investimento. Revista de Administração de Empresas, São Paulo, v. 40, n. 2, p. 74-79, 2000. Disponível em: $\leq$ http://bibliotecadigital.fgv.br/ojs/ index.php/rae/article/view/37698/36447>. Acesso em: 14 jan. 2015.

MINARDI, A. M. A. F.; SAITO, R. Orçamento de capital. Revista de Administração de Empresas, São Paulo, v. 47, n. 3, 2007. Disponível em : $<\underline{\text { http:// }}$ rae.fgv.br/rae/vol47-num3-2007/orcamento-capital $>$. Acesso em: 9 jul. 2014. 
NASCIMENTO, F. M.; BARROS, Z. X.; CAMPO, S.; RODRIGUES, J. G. L.; BARROS, B. S. X. Expansão citrícola do município de Botucatu - SP, obtidas por meio de fotografias aéreas. Applied Research \& Agrotechnology, Guarapuava, v. 3, n. 2, p. 85-90, 2010. Disponível em: $<$ http://revistas. unicentro.br/index.php/repaa/article/view/1007>. Acesso em: 9 jul. 2014.

NORONHA, J. C.; MELLO, C. H. P.; SILVA, C. E. S.; NORONHA, J. C. Opções reais aplicadas à gestão do processo de desenvolvimento de produtos em uma indústria de autopeças. Gestão \& Produção, São Carlos, v. 21, n. 1, p. 77-94, 2014. Disponível em: $<$ http://dx.doi.org/10.1590/S0104530X2014000100006 $>$. Acesso em: 9 jul. 2014.

OLIVEIRA, J. B.; CAMARGO, M, N.; ROSSI, M.; CALDERANO FILHO, B. Mapa pedológico do Estado de São Paulo. Campinas: FAPESP, 1999. $63 \mathrm{p}$.

OLIVEIRA, J. R.; PAMPLONA, E. O. A volatilidade de projetos industriais para uso em análise de risco de investimentos. Gestão \& Produção, São Carlos, v. 19, n. 2, p. 337-345, 2012. Disponível em: $<\underline{\text { http:// }}$ dx.doi.org/10.1590/S0104-530X2012000200008>. Acesso em: 9 jul. 2014.

PAES, A. R.; ESPERANCINI, M. S. T. Análise de rentabilidade da citricultura da região Sul Paulista, sob condições de risco, em três densidades de plantio. Revista Energia na Agricultura, Botucatu, v. 21, n. 1, p. 18-33, 2006.

PAES, A. R.; ESPERANCINI, M. S. T.; KUROSAKI, A. B.; SOUZA, F. G. A. Modelo de previsão econômica para tomada de decisão em condições de risco na citricultura. Citrus Research \& Technology, Cordeirópolis, v. 26, n. 2, p. 9-22, 2005. Disponível em: $<$ http://revistalaranja.centrodecitricultura.br/edicoes/ down.php?idedicao $=13$ \&arquivo $=\mathrm{v} 26 \% 20 \mathrm{n} 2 \% 20$ art01\%20MODELO $\% 20$ DE\%20PREVIS\%C3O. pdf $>$. Acesso em: 8 jul 2014.

PAES, A. R.; ESPERANCINI, M. S. T.; SOUZA, F. G. Análise de rentabilidade da produção de laranja para indústria em fase produtiva sob condições de risco em dois sistemas de produção no estado de São Paulo. In: CONGRESSO DA SOCIEDADE BRASILEIRA DE ECONOMIA E SOCIOLOGIA RURAL, 42., 2004, Cuiabá. Anais... Brasília: SOBER, 2004. CD-ROM.
PALISADE CORPORATION. @Risk para Excel. Versão 6.3.0 edição industrial. Newfield: Palisade Corporation, 2014.

PAULILLO, L. F.; ALMEIDA, L. M.; VIEIRA, A. C. Citricultura paulista: entraves institucionais e organizacionais. Citrus Research \& Technology, Cordeirópolis, v. 27, n. 2,p. 185-212, 2006. Disponível em: $<$ http://revistalaranja.centrodecitricultura.br/ edicoes $/$ down.php?idedicao $=15 \&$ arquivo $=02$ citricultura.pdf $>$. Acesso em: 8 jul. 2014.

PIMENTEL, L. D.; SANTOS, C. E. M.; WAGNER JÚNIOR, A.; SILVA, V. A. BRUCKNER, C. H. Estudo de viabilidade econômica na cultura da noz-macadâmia no Brasil. Revista Brasileira de Fruticultura, Jaboticabal, v. 29, n. 3, p. 500-507, 2007. Disponível em: $<$ http://dx.doi.org/10.1590/ $\underline{\mathrm{S} 0100-29452007000300018>\text {. Acesso em: } 7 \text { jul }}$ 2014.

ROSS, S. A.; WESTERFIELD, R. W.; JORDAN, B. D. Princípios de administração financeira. 2. ed. São Paulo: Editora Atlas, 2002. 523p.

SANTOS, R. M.; NÄÄS, I. A.; MOLLO NETO, M.; VENDRAMETTO, O. An overview on the Brazilian orange juice production chain. Revista Brasileira de Fruticultura, Jaboticabal, v. 35, n. 1, p. 218-225, 2013. Disponível em: $<$ http://dx.doi. org/10.1590/S0100-29452013000100025>. Acesso em: 7 jul. 2014.

SIMÕES, D.; SILVA, R. B. G.; SILVA, M. R. Composição do substrato sobre o desenvolvimento, qualidade e custo de produção de mudas de Eucalyptus grandis Hill ex Maiden $\times$ Eucalyptus urophylla S. T. Blake. Ciência Florestal, Santa Maria, v. 22, n. 1, p. 91-100, 2012. Disponível em: $<$ http://dx.doi.org/10.5902/198050985082>. Acesso em: 7 jul. 2014.

SCHWARZ, G. Estimating the dimension of a model. Annals of Statistics, Philadelphia v. 6, n. 2 p. 461464, 1978.

SOLOMON, E. The arithmetic of capital-budgeting decisions. The Journal of Business, Chicago, v. 29, n. 2, p. 124-129, 1956. Disponível em: $<$ http:// www.jstor.org/discover/10.2307/2351103?uid $=3737$ $664 \&$ uid $=2129$ \&uid $=2134 \&$ uid $=2 \&$ uid $=70 \&$ uid $=4$ $\underline{\& \text { sid }=21104281071367>}$. Acesso em: 9 jul. 2014. 
SOUZA, A.; CLEMENTE, A. Decisões financeiras e análise de investimentos: fundamentos, técnicas e aplicações. São Paulo: Atlas, 2008. 200p.

SPEARMAN, C. General intelligence objectively determined and measured. American Journal of Psychology, Washington, v. 15, n 2. p. 201-292, 1904. Disponível em: <https://www.psych.umn. edu/faculty/waller/classes/FA2010/Readings/ Spearman1904.pdf>. Acesso em: 9 jul. 2014.

TOFFANO, L.; FISCHER, I. H.; BLUMER, S.; PASCHOLATI, S. F. Potencial do flavedo (epicarpo) de Citrus aurantifolia cv. Tahitino controle do bolor verde e da antracnose em citros. Summa Phytopathologica, Botucatu, v. 38, n. 1. p. 61-66, 2012. Disponível em: <http://dx.doi.org/10.1590/ $\underline{\mathrm{S} 0100-54052012000100010>\text {. Acesso em: } 9 \text { jul. }}$ 2014.
TRIGEORGIS, L. Real options: managerial flexibility and strategy in resouce allocation. Cambridge: The MIT Press, 1996. 427p.

USDA - United States Department of Agriculture. Risk management: executive summary may 2006. Disponível em: < $\underline{\text { http://www.usda.gov/documents/ }}$ Farmbill07riskmgmtsum1.pdf $>$. 2007. Acesso em: 8 jul. 2014.

VIEIRA FILHO, J. E. R.; SILVEIRA, J. M. J. Mudança tecnológica na agricultura: uma revisão crítica da literatura e o papel das economias de aprendizado. Revista de Economia e Sociologia Rural, Brasília, v. 50, n. 4, p. 721-742, 2012. Disponível em: $<$ http://dx.doi.org/10.1590/S010320032012000400008>. Acesso em: 9 jul. 2014.

Woiler, S.; MAthias, W. F. Projetos: planejamento, elaboração e análise. São Paulo: Atlas, 1988. 294p. 